\title{
Improvement of subgrade soil by blending tyre driven aggregate (TDA)
}

\author{
Naeem Mangi ${ }^{1}$, Faisal Ahmed Sarki ${ }^{2}$ \\ ${ }^{1}$ Department of Civil Engineering, \\ Quaid-e-Awam University of Engineering, Science \& Technology, Nawabshah, Pakistan, \\ ${ }^{1}$ naeem08ce30@gmail.com , ${ }^{2}$ faisal.sarki21@gmail.com
}

\begin{abstract}
Pavements are largely affected by the inherent variability of soil nature which may be change in type and condition. Subgrade soils are characterized by their resistance to deformation under load, which can be measured in terms of strength and stiffness. The subgrade strength of soil is the key factor to ensure the sustainability of the pavement and is considered as of prime importance for design of pavement. If pavements are constructed on weak subgrade soils, then there are chances of possible settlement and subsequent pavement failure. The aim of study is to improve the bearing pressure of existing subgrade soil using tyre driven aggregates obtained from scrap tyre. The California Bearing Ratio (CBR) tests were performed on existing subgrade soil and the improved soil with $5 \%, 15 \%$, and $30 \%$ replacement of tyre driven aggregates. The maximum dry density of soil was found to be $1636 \mathrm{~kg} / \mathrm{m} 3$ at optimum moisture content of $21.26 \%$. The CBR of the existing ground was measured as $3.90 \%$. It was revealed that CBR value was improved by $5.1 \%, 10 \%$ and $28.7 \%$ of existing value when subgrade grade soil was replaced by 5\%, $15 \%$ and at $30 \%$ demolished aggregates, respectively
\end{abstract}

Key words: Soil Improvement, Subgrade Stabilization, tyre driven aggregate (TDA), California Bearing Ratio (CBR).

\section{INTRODUCTION}

The subgrade comprises the base material for the highway structure, as the highway eventually lay on in-situ soil subgrade. Subsequently the design of the highway structure is influenced by the properties of the subgrade. One of the significant roles of highway pavement structure is to diminish the load transfer to the subgrade. Highway pavement structure comprise of different layers of which the base layer is subgrade. Bearing capacity of subgrade soil largely affects the design and performance of pavement structure of road. The road pavement structures are to a great extent influenced by the inconstancy of soil nature which may change in type and condition. Pavements which are built on loose subgrade soil having low strength are decisive to settlement and causing the failure of highway. Therefore, subgrade soil having low bearing pressure should be improved; else it can hamper the pavement's performance and life. This study focuses on improving the bearing pressure of existing subgrade soil by mixing it with tyre driven aggregates (TDA) obtained from scrap tyre.

\section{LiteratURE REVIEW}

Discarded vehicle tyres constitute one important part of solid waste, which had historically been disposed of into landfills. An emerging reuse is the production of concrete, in which waste- tyre rubber particles in part replace the natural aggregates. This has an additional advantage of saving the natural aggregates used in concrete making. Recycled waste-tyre rubber is a rising material in the construction industry due to its low weight, elasticity, energy-absorption, heat and sound proofing characteristics. Waste-tyre rubber can be used as chipped (20-30 mm) or crumbed (3-10 mm) or ash rubber (less than $1 \mathrm{~mm}$ ) [1]. The waste-rubber tyre particles cut into $20 \mathrm{~mm}$ size. Its benefits are numerous such as reduction of the cost of aggregates and disposal, prevention of environmental degradation, and increase in life span of landfill areas [2]. Tire-derived aggregate (TDA), a recycled product made by shredding scrap tires into sizes ranging from $12 \mathrm{~mm}$ to $100 \mathrm{~mm}$, can be used to replace natural aggregates in civil engineering applications. Each year, one billion scrap tires are discarded worldwide. Over 250 million of them are in the United States and 30 million in Canada [3]. In the 1990s, tire recycling and reuse in North America and worldwide have increased considerably, with the aim of reducing the harmful effects of scrap tires on the environment. For instance, scrap tires in landfills provide an attractive habitat for mosquitoes and rodents [4]. In addition, stockpiling scrap tires in tire landfills is hazardous and may cause uncontrolled fires such as the 1990 tire fire in Hagersville, Ontario, Canada [5]. The progressive development of tire recycling and reuse has resulted in a significant decrease in the disposal of scrap tire stockpiles in landfills. According to the Scrap Tire Management Council in the United States, in 2000, $70 \%$ of scrap tires were recycled 
as compared with only 6\% in 1990. The 2017 Rubber Manufacturers Association report states that over $43 \%$ of scrap tires generated annually in the United States were recycled as tire-derived fuel (TDF). Although $25 \%$ of the tires were utilized in ground rubber applications, only $7.9 \%$ were recycled in civil engineering projects. Hence there is a current direction to deviate a greater portion of the tires from being used as TDF to be used in civil applications to reduce the environmental concerns associated with burning tires. TDA has outstanding properties making it suitable for use in a wide variety of civil applications, e.g., embankments, trench backfilling and road subgrades $[6,7,8,9]$. In comparison to conventional backfill aggregates, TDA is an inexpensive, lightweight material. The specific gravity of TDA ranges from 1.15 to 1.21 , whereas the specific gravity of natural backfills ranges from 2.55 to 2.75 [10]. In addition, the cost of scrap tires is about $25 \%$ of the cost of conventional backfill [11]. As reported in [12], the permeability of TDA is ten times that of gravel used in drainage applications. Many studies have been conducted to investigate the use of TDA in embankments, buried infrastructure and trench fill projects $[13,14]$. The researchers conducted research on shredded scrap tires blended with subbase soils under flexible pavements and determined the shear strength and stress strain relationship of tyre chip and a mixture of sand and tyre chips. They found out the stiffness and strength properties for tyre shreds and sand mixture [15]. The study was conducted on sand mixed with rubber chips. Compressibility tests and triaxial tests were conducted the stress strain relations and strength parameters were studied. He concluded that the blends were useful as lightweight embankment fill on weak foundation soils and retaining wall backfill material since the sand rubber mixtures were significantly lighter than $100 \%$ sand mixtures [16, 17].

\section{Material Collection ANd Laboratory EXPERIMENTS}

\subsection{COLLECTION OF SAMPLE}

The soil was excavated from the vicinity of QUEST Nawabshah near Mechanical Engineering Workshop at the depth of 1 meter using pit method as shown in Fig.1. Shredded rubber was obtained from scrap tyre.

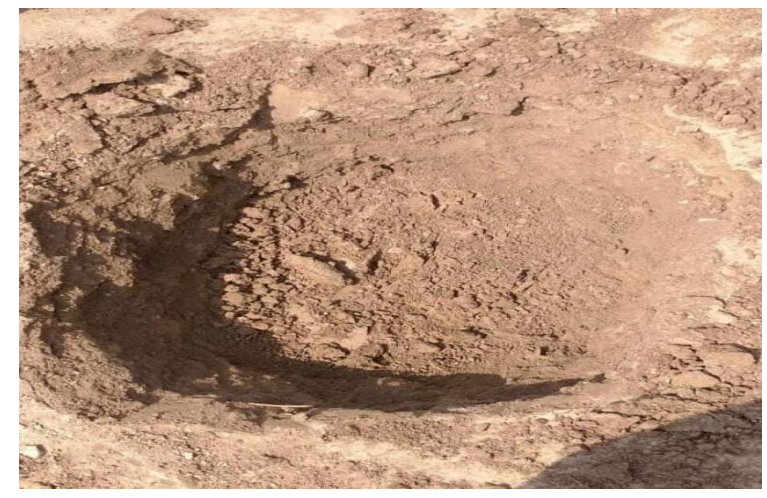

Fig: 1. Vicinity of QUEST Nawabshah from where soil sample was taken

\subsection{Mixing OF MATERIAL}

The shredded rubber tyre aggregate were mixed with soil sample collected from the vicinity of QUEST, Nawabshah by weight. The mixtures were prepared with replacement of soil sample with $5 \%, 15 \%$, and $30 \%$ of tyre driven aggregates.

\subsection{EXPERIMENTAL WORK}

During lab experiment work, following properties of the soil were determined.

(A) Water Content (W \%): (ASTM D2216 - 98) [20]

(B) Optimum Moisture Content (OMC) and Maximum Dry Density (MDD) from Modified Proctor Test (ASTM D 1557 - 02) [19]

(C) California Bearing Pressure (ASTM D 1883-99) [18]

\section{RESULTS AND DISCUSSIONS}

From standard proctor test the maximum dry density of soil sample was found to be $1636 \mathrm{~kg} / \mathrm{m} 3$ at the optimum moisture content of $21 \%$ as shown in Fig.2.

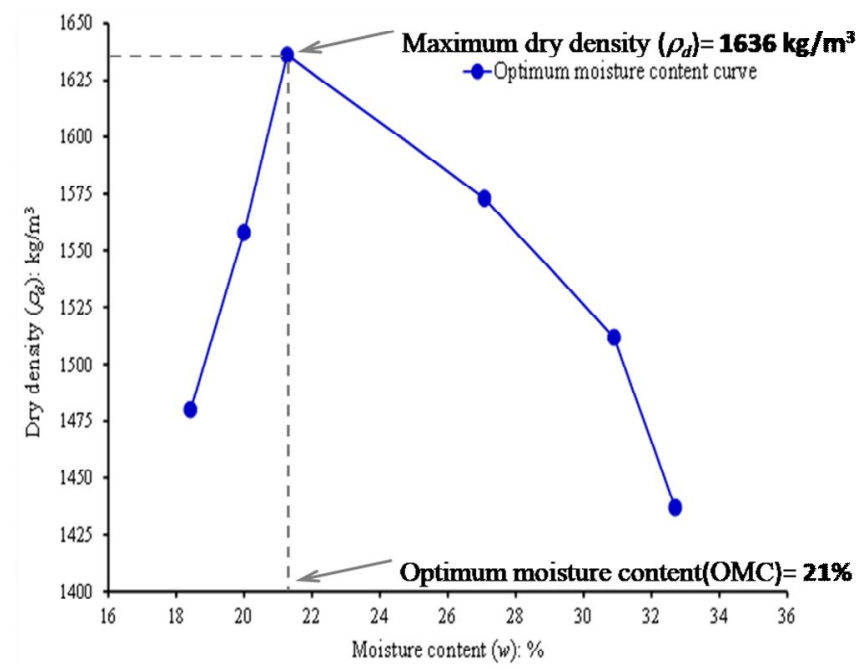

Fig: 2 Optimum Moisture Content (OMC) curve

\subsection{LOAD PENETRATION CURVE OF EXISTING SUBGRADE SOIL}

Fig. 3 show that the penetration of plunger (in $\mathrm{mm}$ ) against applied load (hence bearing pressure) for the CBR mould of existing subgrade sample. It can be seen from the figure that the penetration increases linearly with increment of load. The standard value of CBR is taken at $2.5 \mathrm{~mm}$ or $5 \mathrm{~mm}$. if the measured CBR value at $5 \mathrm{~mm}$ penetration is found to be larger than that at $2.5 \mathrm{~mm}$. in this case, CBR test should be repeated. As from graph, bearing pressure at $2.5 \mathrm{~mm}$ was found to be $2.59 \mathrm{~kg} / \mathrm{cm} 2$ and $4.12 \mathrm{~kg} / \mathrm{cm} 2$ at $5 \mathrm{~mm}$. 


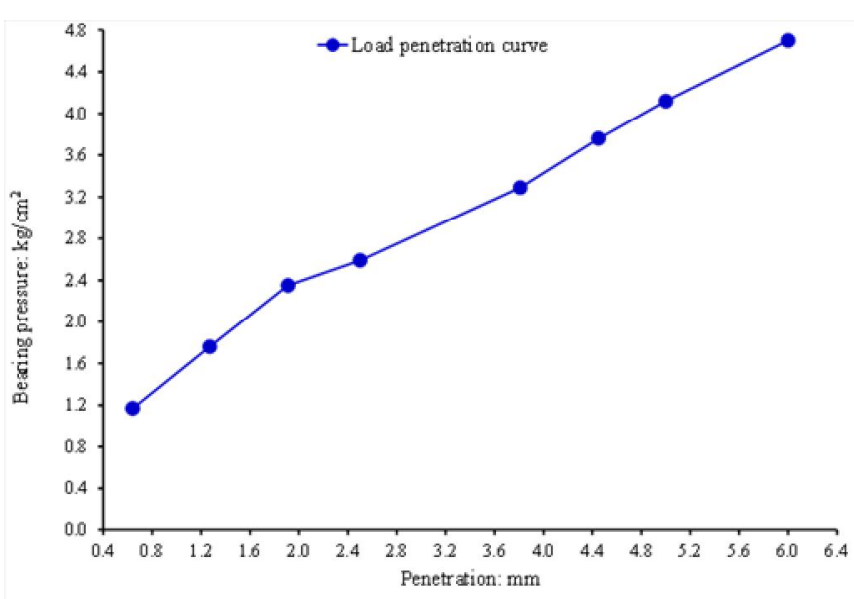

Fig. 3. Load penetration curve of existing subgrade soil

\subsection{LOAD PENETRATION CURVE OF IMPROVED SOIL BLENDED WITH $5 \%$ TYRE AGGREGATES}

Fig: 4 shows that the penetration of plunger (in $\mathrm{mm}$ ) against applied load (hence bearing pressure) for the CBR mould of existing subgrade sample. It can be seen from the figure that the penetration increases linearly with increment of load. The standard value of CBR is taken at $2.5 \mathrm{~mm}$ or $5 \mathrm{~mm}$. if the measured CBR value at $5 \mathrm{~mm}$ penetration is found to be larger than that at $2.5 \mathrm{~mm}$. in this case, CBR test should be repeated. As from graph, bearing pressure at $2.5 \mathrm{~mm}$ was found to be $2.76 \mathrm{~kg} / \mathrm{cm} 2$ and $4.35 \mathrm{~kg} / \mathrm{cm} 2$ at $5 \mathrm{~mm}$.

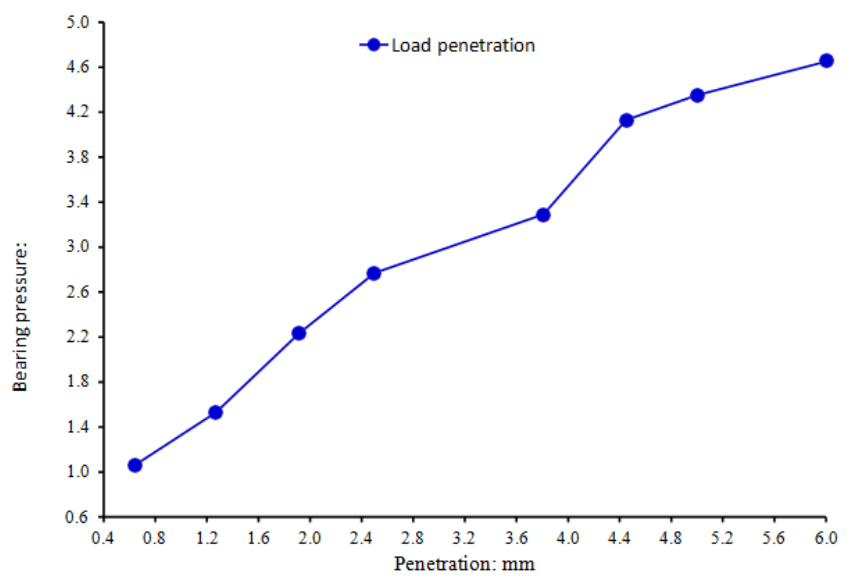

Fig. 4. Load penetration curve of improved soil at 5\% replacement

\subsection{LOAD PENETRATION CURVE OF IMPROVED SOIL BLENDED WITH 15\% AGGREGATES}

Fig: 5 shows that the penetration of plunger (in $\mathrm{mm}$ ) against applied load (hence bearing pressure) for the CBR mould of existing subgrade sample. It can be seen from the figure that as the penetration increases linearly with increment of load. The standard value of CBR is taken at $2.5 \mathrm{~mm}$ or $5 \mathrm{~mm}$. if the measured CBR value at $5 \mathrm{~mm}$ penetration is found to be larger than that at $2.5 \mathrm{~mm}$. in this case, CBR test should be repeated. As from graph, bearing pressure at $2.5 \mathrm{~mm}$ was found to be $2.94 \mathrm{~kg} / \mathrm{cm} 2$ and $4.53 \mathrm{~kg} / \mathrm{cm} 2$ at $5 \mathrm{~mm}$.

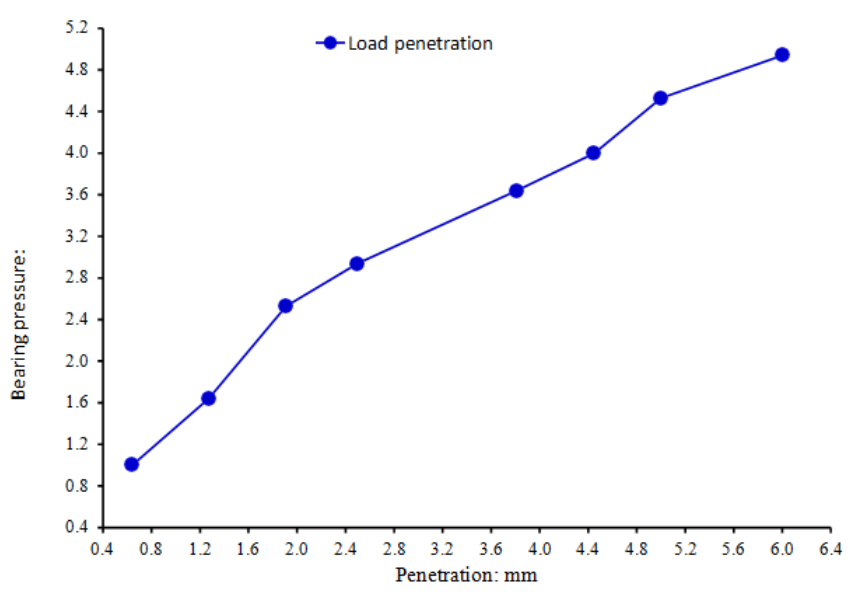

Fig. 5. Load penetration curve of improved soil at $15 \%$ replacement

\subsection{LOAD PENETRATION CURVE OF IMPROVED SOIL BLENDED WITH 30\% AGGREGATES}

Fig: 6 shows that the penetration of plunger (in $\mathrm{mm}$ ) against applied load (hence bearing pressure) for the CBR mould of existing subgrade sample. It can be seen from the figure that as the penetration increases linearly with increment of load. The standard value of CBR is taken at $2.5 \mathrm{~mm}$ or $5 \mathrm{~mm}$. if the measured CBR value at $5 \mathrm{~mm}$ penetration is found to be larger than that at $2.5 \mathrm{~mm}$. in this case, CBR test should be repeated. As from graph, bearing pressure at $2.5 \mathrm{~mm}$ was found to be $3.41 \mathrm{~kg} / \mathrm{cm} 2$ and $5.29 \mathrm{~kg} / \mathrm{cm} 2$ at $5 \mathrm{~mm}$.

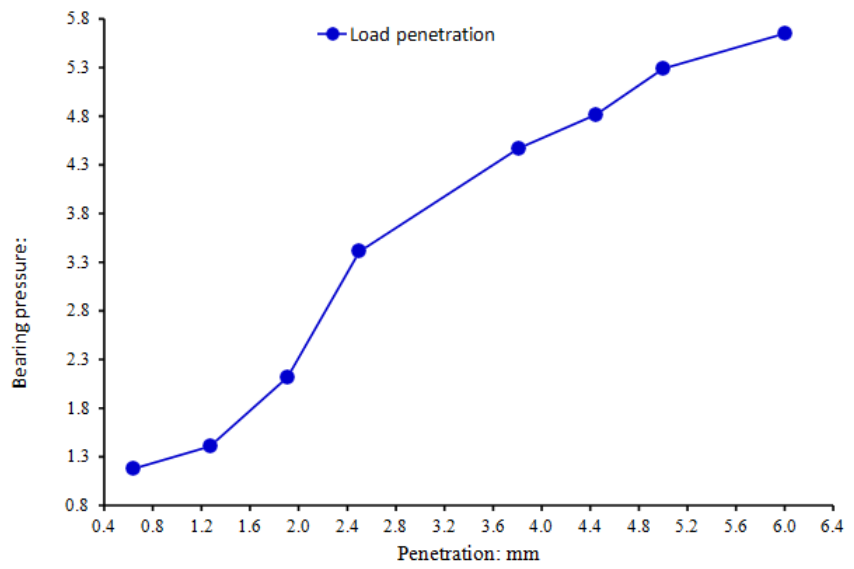

Fig. 6. Load penetration curve of improved soil at $30 \%$ replacement

\subsection{LOAD PENETRATION CURVE OF EXISTING AND IMPROVED SOIL AT 5\%, $15 \%$ AND $30 \%$.}

As it is clear from the graph that for the given load (bearing pressure), the value of penetration decreases for the improved soil at $(5 \%, 15 \%$ and $30 \%)$ and slope of the improved soil increases substantially as shown in Fig. 7. The slope in load penetration diagram represents the stiffness of the soil. The decrease in the penetration of improved soil for the given bearing pressure is due to the increase in the stiffness of the soil. 


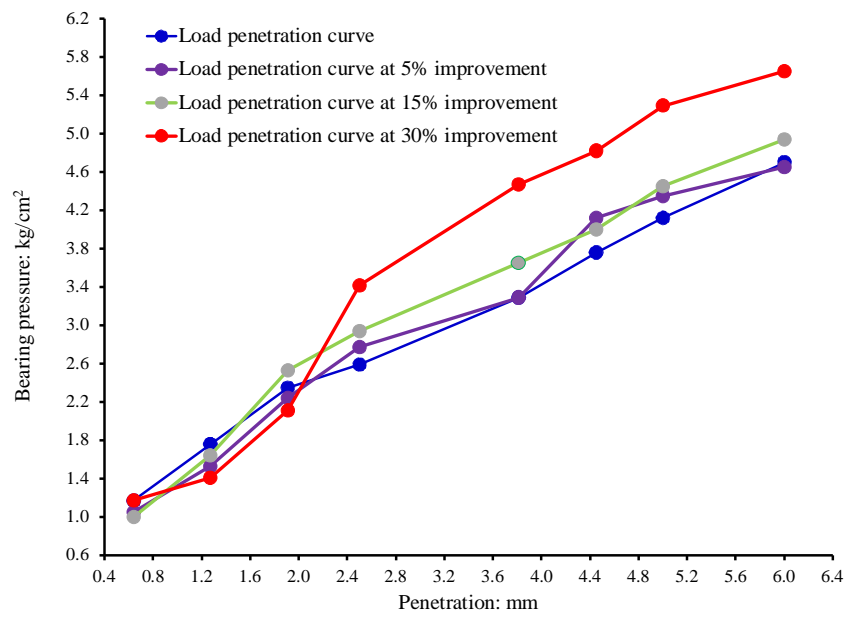

Fig. 7. Load penetration curve of existing and improved soil at (5\%, $15 \%, 30 \%$ ) replacement

\subsection{COMPARISON OF CBR VALUE OF EXISTING AND IMPROVED SOIL AT $5 \%, 15 \% \& 30 \%$ REPLACEMENT OF TYRE DRIVEN AGGREGATES}

Fig. 8 compared the CBR values of existing and improved subgrade soil. The CBR value was improved by $5.1 \%$ of CBR value of existing soil at the $5 \%$ replacement of tyre driven aggregate, $10 \%$ of $\mathrm{CBR}$ value of existing soil at $15 \%$ replacement of tyre driven aggregate and $28.7 \%$ of CBR value of existing soil at $30 \%$ replacement of tyre driven aggregate.

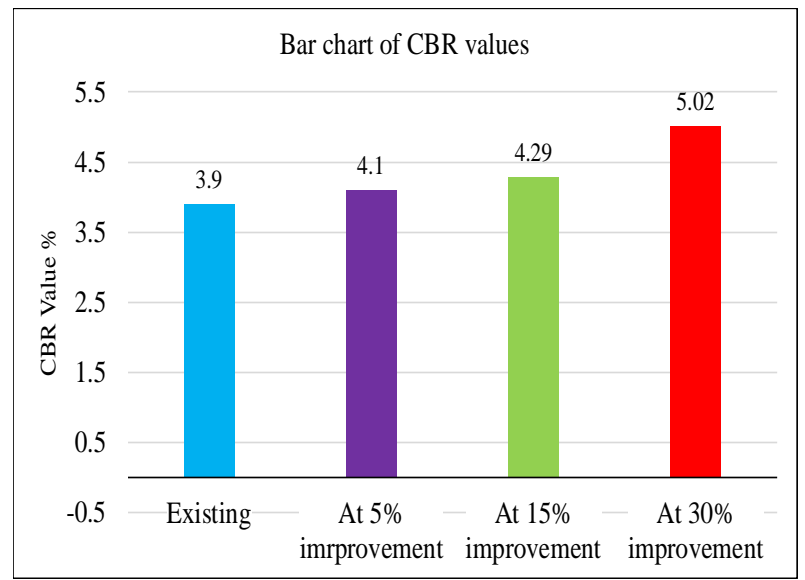

Fig. 8. Comparison of CBR value of existing and improved

\section{ConClusion}

Based on the study and laboratory results following conclusions can be drawn.

(i) Owing to the standard proctor test of soil compaction, the maximum dry density of soil (clay) was found to be 1636 $\mathrm{kg} / \mathrm{m} 3$ at the optimum moisture content of $21.26 \%$ whereas natural moisture content of the soil in its existing condition was found to be $26.5 \%$.

(ii) The subgrade bearing pressure of the existing soil was found to be $3.90 \%$ at $5 \mathrm{~mm}$ penetration, with the addition of tyre driven aggregates to existing soil increase in the stiffness of soil and decrease in the penetration for the given load was observed.

(iii) At 5\% replacement of tyre driven aggregates, CBR value of improved subgrade was found to be $4.1 \%$ at $5 \mathrm{~mm}$ penetration.

(iv) At $15 \%$ replacement of tyre driven aggregates, CBR value of improved subgrade was found to be $4.29 \%$ at $5 \mathrm{~mm}$ penetration.

(v) At $30 \%$ replacement of tyre driven aggregates, CBR value of improved subgrade was found to be $5.02 \%$ at $5 \mathrm{~mm}$ penetration.

\section{REFERENCES}

[1]. Ahn, I.-S., Cheng, L., Fox, P.J., Wright, J., Patenaude, S., Fujii, B., 2014. Material properties of large-size tire derived aggregate for civil engineering applications. J. Mater. Civ. Eng. 27 (9).

[2]. Anastasiadis, A., Senetakis, K., Pitilakis, K., 2012. Small-strain shear modulus and damping ratio of sand-rubber and gravel-rubber mixtures. Geotech. Geol. Eng. 30 (2), 363-382

[3]. Ashari Ghomi, M., 2018. Large-scale triaxial testing of sustainable TDA backfilling alternatives. Master's thesis.

Dalhousie University, https://dalspace.library.dal.ca/bitstream/

[4]. Ashari, M., El Naggar, H., Martins, Y., 2017. Evaluation of the physical properties of TDA sand mixtures. In: GeoOttawa, the 70th Canadian Geotechnical Conference Ottawa. Canadian Geotechnical Society, Berlin.

[5]. Edil, T. B., and Bosscher, P. J. (1994), Engineering properties of tire chips and soil mixtures, Geotechnical Testing J., ASTM, Vol. 17, No. 4, 453-464.

[6]. ASTM International, West Conshohocken, PA, USA. Benson, C.H., Olson, M.A., Bergstrom, W.R., 1996. Temperatures of insulated landfill liner. Transp. Res. Rec. 1534 (1), 24-31. https://doi.org/10.3141/1534-05.

[7]. Bernal, A., Lovell, C.W., Salgado, R., 1996. Laboratory Study on the Use of Tire Shreds and Rubber-Sand in Backfilled and Reinforced Soil Applications. Publication FHWA/ IN/JHRP-96/12. Joint Highway Research Project, Indiana Department of Transportation and Purdue University, West Lafayette, Indiana. https://doi.org/10. 5703/1288284313259

[8]. Bosscher, P.J., Edil, T.B., Eldin, N.N., 1992. Construction and performance of shredded waste-tire test embankment. Transp. Res. Rec. 1345, 44-52.

[9]. Edil, T.B., Park, J.K., Kim, J.Y., 2004. Effectiveness of scrap tire chips as sorptive drainage material. J. Environ. Eng. 824-831.

[10]. Edil, T.B., Park, J.K., Kim, J.Y., 2004. Effectiveness of scrap tire chips as sorptive drainage material. J. Environ. Eng. 824-831. 
[11]. Edil, T.B., 2005. A review of mechanical and chemical properties of shredded tires and soil mixtures. InRecycled Materials in Geotechnics, pp. 1-21.

[12]. El Naggar, H., Soleimani, P., Fakhroo, A., 2016. Strength and stiffness properties of green lightweight fill mixtures. Geotech. Geol. Eng. 34 (3), 867-876. https://doi.org/10. 1007/s10706-016-0010-1.

[13]. Fox, P.J., Thielmann, S.S., Sanders, M.J., Latham, C., Ghaaowd, I., McCartney, J.S., 2018. Large-scale combination direct shear/simple shear device for tire-derived aggregate. Geotech. Test. J. 41 (2), 340-353.

[14]. Ghaaowd, I., McCartney, J.S., Thielmann, S.S., Sanders, M.J., Fox, P.J., 2017. Shearing behavior of tire-derived aggregate with large particle size. I: Internal and concrete interface direct shear. J. Geotech. Geoenviron. Eng. $143 \quad$ (10), $04017078 . \quad$ https://doi. org/10.1061/(ASCE)GT.1943-5606.0001775.

[15]. Hoppe, E.J., 1998. Field study of shredded-tire embankment. Transp. Res. Rec. 1619 (1), 47-54. https://doi.org/10.3141/1619-06.

[16]. Rao G.V and Dutta R.K (2001), "Utilisation of shredded tyres in highway engineering", Proceedings of the International seminar on sustainable development in road transport,

New Delhi, pp 257-268

[17]. Cabalar, A. F. Direct Shear Tests on Waste Tires-Sand Mixtures. Geotechnical and Geological Engineering, Volume 29, Issue 4, 2011, pp. 411-418.

[18] ASTM (1999), Standard test method for CBR (California Bearing Ratio) of laboratory-compacted soils, ASTM D 1883-99.

[19] ASTM (2002), Standard Test Methods for Laboratory Compaction Characteristics of Soil Using Modified Effort, ASTM D D1557-02.

[20] ASTM (1998), Standard Test Method for Laboratory Determination of Water (Moisture) Content of Soil and Rock by Mass, D2216 - 98 . 